\title{
GROUND WATER IN QUINCY VALLEY, WASHINGTON.
}

\author{
By A. T. Schwennesen and O. E. Meinzer.
}

\section{INTRODUCTION.}

IOCATION AND AREA.

Quincy Valley is in Grant County, Wash., a little south and east of the center of the State (fig. 5). The lowland to which the term Quincy Valley is locally applied is not, however, a true valley in the usual sense of that word, for it is nearly as broad as it is long and is more appropriately called a basin. This basin is bounded on the north by the Badger Hills, on the south by the Frenchman Hills, on the west by Babcock Ridge and other low swells along the brink of the Columbia River gorge, and on the east by the high land east of Moses Lake. Its area is approximately 600 square miles.

The northern part of the basin is crossed by the transcontinental line of the Great Northern Railway; the' eastern part is reached by branch lines of the Northern Pacific and Chicago, Milwaukee \& St. Paul railways; and the region south of the Frenchman Hills is traversed by the main line of the Chicago, Milwaukee \& St. Paul Railway, which can be reached without difficulty from the southern part of the basin by crossing the Frenchman Hills.

The principal towns in the basin are Ephrata and Quincy, both in its northern part, on the Great Northern Railway. Neppel is at the terminus of the branch line of the Chicago, Milwaukee \& St. Paul Railway.

\section{SCOPE OF INVESTIGATION.}

For many years stockmen along Crab Creek have used the water from the stream to irrigate wild grass on the adjacent bottom lands, but within the last few years water has been pumped for irrigation in certain parts of the valley. Near Moses Lake some tracts are irrigated with water pumped from the lake but in other parts of the basin the water is pumped from wells. Most of the irrigated lands are in apple orchard, but a great variety of other crops, including alfalfa, corn, melons, vegetables, and small fruits, are raised by irrigation for home consumption and for the local market. 
Repeated advances in the price of fuel for internal-combustion engines during the last few years has greatly increased the cost of irrigation. The burden has been especially heavy on irrigators who must pump the water from great depths and who are irrigating

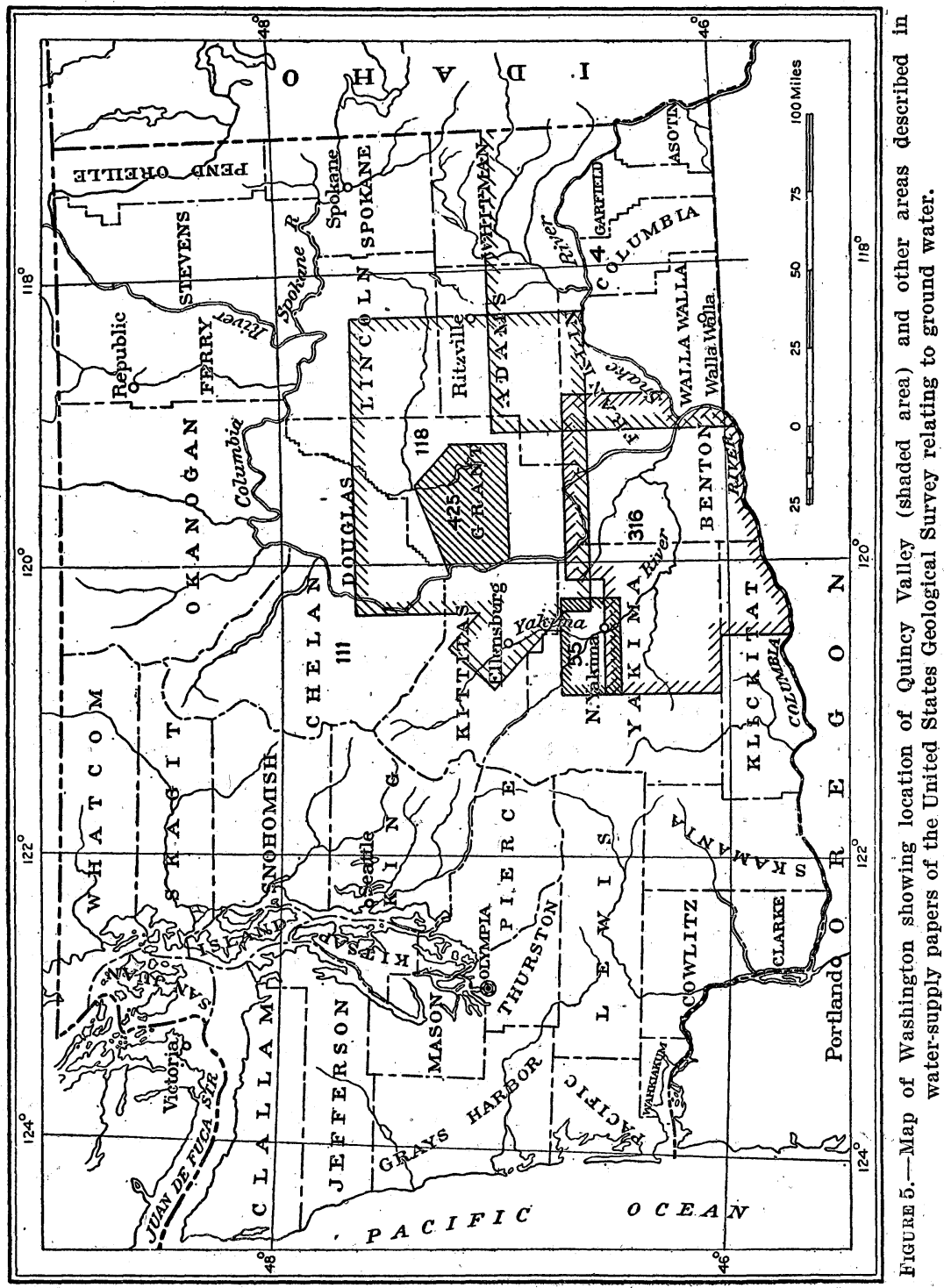

young orchards that are not yet bearing. In some orchards the trees have suffered through lack of water because of the inability of the owners to pay the fuel bills.

From time to time various projects for supplying the basin with water for irrigation have been considered. In $1909 \mathrm{Mr}$. Joseph 
Jacobs made an investigation for the Quincy Valley Water Users' Association to discover the most practicable and economical source of water. In his report, ${ }^{1}$. which was published by the Washington Geological Survey, Wenatchee River and Wenatchee Lake were considered the most feasible sources, and plans were made for a gravity system thus supplied, providing for the irrigation of 435,000 acres in Quincy Valley and in the region to the south, between the Frenchman Hills and Saddle Mountain. The estimated cost of the project was $\$ 43,700,000$, or approximately $\$ 100$ an acre. No means have yet been found for financing the project.

The residents of the basin have long looked to the near-by Columbia as a possible source of cheap electric power that could be used for pumping. It is pointed out that the rapids of the river afford power sites, that these rapids are now serious obstacles to navigation, and that in connection with the construction of works at the rapids to make them navigable provision could be made, at a proportionately small charge, for utilizing their power.

In 1909 and 1911 Army engineers made surveys of the Columbia from the mouth of Snake River to Wenatchee to determine the feasibility of such a combined project ${ }^{2}$ but reported adversely on it, for the reason that the present and prospective commerce on the Columbia would not warrant the expenditure of that proportion of the total cost which would have to be charged against improvement of navigation. In view of the small amount of commerce to be benefited, it was concluded that the development of power should be considered the primary object and that the needs of navigation could be considered only incidentally.

If the project is considered solely as a means of obtaining power, the question at once arises whether the demand for power is sufficient to justify the undertaking. Neither the Federal Government nor private capitalists will undertake extensive power developments without the assurance of an adequate and certain market for the power. Irrigators in Quincy Valley recognize many advantages of electric power over power generated by internal-combustion engines, and if electric power had the additional advantage of cheapness it would doubtless almost completely replace that furnished by internal-combustion engines. The number of pumping plants and the resulting market for power will be determined by several factors, including topography, soil, and depth to water, but perhaps chiefly by the quantity of ground water obtainable. The importance of an adequate supply of ground water was recognized by the resi-

\footnotetext{
1 Landes, Henry, Mangum, A. W., Benson, H. K., Saunders, E. J., and Jacobs, Joseph, A preliminary report on the Quincy Valley irrigation projects: Washington Geol. Survey Bull. 14, 1912.

${ }^{2}$ Kutz, C. W., 62d Cong., 2d sess., H. Doc. 693.
} 
dents of the basin and it was the fundamental reason for their request for the investigation on which this report is based.

The material for the present report was collected by A. T. Schwennesen, who spent about two and one-half months in the field in the fall of 1916. During two weeks of this time Mr. Schwennesen was accompanied by $\mathrm{O}$. E. Meinzer, and together they made a reconnaissance of the region adjacent to the basin. The report was written chiefly by Mr. Schwennesen, but Mr. Meinzer collaborated in certain parts. F. F. Henshaw, also of the Geological Survey, furnished valuable data and estimates on stream flow and evaporation in the region from 1910 to 1913 , inclusive. The present preliminary report on the region will be followed by a full report containing the detailed data and maps.

\section{ACKNOWLEDGMENTS.}

The authors gratefully acknowledge the unfailing courtesy and willingness with which residents of the basin complied with requests for information, and are under obligations to the drillers for assistance in collecting well records. Special thanks are due Mr. Louis Mullerleile, of Quincy, who placed at the disposal of the Survey a large amount of material that he had collected relating to wells in the region.

\section{TOPOGRAPHY.}

\section{TOPOGRAPHIC FEATURES OF CENTRAL WASHINGTON.}

Quincy Valley is a part of the Walla Walla Plateau, which is the northern section of the Columbia Plateau province. The Walla Walla Plateau extends from the Cascade Mountains eastward to the Coeur d'Alene and Bitterroot mountains, and from the Colville Mountains and Okanogan highlands southward to the Blue Mountains in Oregon and Idaho, and to the basins of the Harney section in south-central Oregon. It consists essentially of great expanses of nearly level or gently sloping ground, interrupted by hills and by deep trenchlike valleys.

In general its surface conforms to the structure of the underlying basalt, being nearly level where the beds of basalt lie nearly horizontal, forming ridges where these beds have been upwarped into anticlines, and forming broad valleys where they have been downwarped into synclines. The canyons, locally known as coulees, are characteristic of the region. At many places they extend across the ridges, indicating that the streams by which they were formed existed before the ridges and persisted in their courses by cutting into the basalt beds when those beds were uplifted. The canyons of Columbia and Snake rivers and the large coulees which formerly contained 


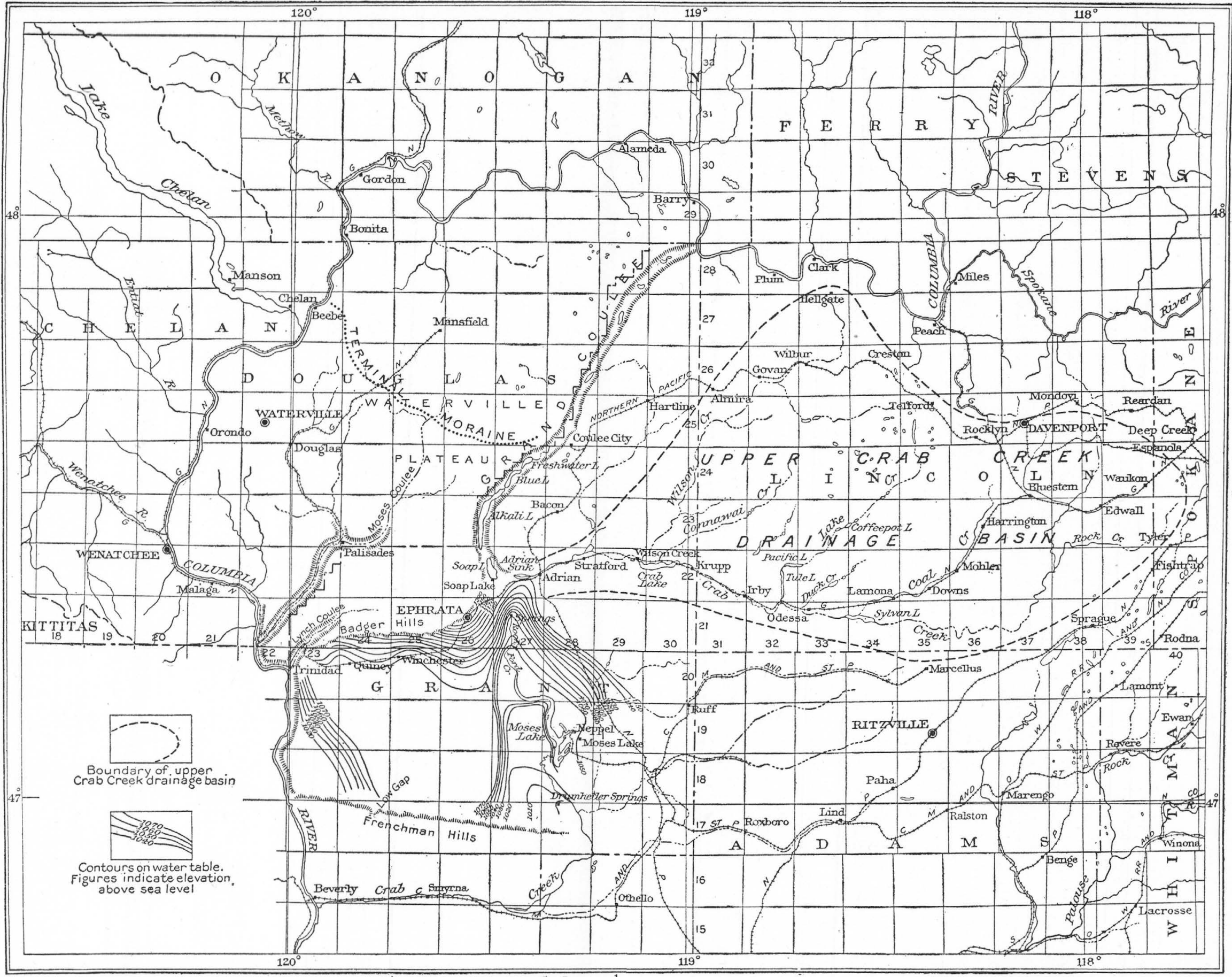

$10 \quad$ Sçale $\frac{1}{1,000,000}$ 40 Miles MAP OF QUINCY VALLEY, WASH.; AND ADJACENT AREAS, SHOWING CONTOURS OF THE WATER TABLE AND AREAS CONTRIBUTING WATER 
rivers, such as Grand Coulee and Moses Coulee, are conspicuous examples of intensive stream trenching.

\section{TOPOGRAPHIC FEATURES OF THE REGION AROUND QUINCY VALIEY.}

The form of Quincy Valley and of the principal features that bound it are in accord with the relations existing between structure and surface forms throughout the Walla Walla Plateau. Structurally Quincy Valley is a broad, shallow basin, defined on the north by the fold that forms the Badger Hills, on the south by the arch of the Frenchman Hills, on the west by the monoclinal slope projected eastward from Table Mountain across the gorge of Columbia River, and on the east by a less obvious westerly dip of the rocks.

West of Quincy Valley is the gorge of Columbia River-a great trench cut into the resistant basalt to a depth of 800 feet and walled in many places by nearly vertical cliffs of basalt. The gorge is largely independent of the present structure, for it cuts squarely across such important east-west structural features as the Badger Hills and Frenchman Hills. Opposite Quincy Valley the gorge runs parallel to the general trend of Table Mountain. Here its course may have been controlled to some extent by the structure, but that the control was not complete is shown by the fact that the monoclinal eastward dip seen in Table Mountain is continued across the gorge.

The largest of the coulees in this region, and the one most closely related to the geologic history of Quincy Valley, is Grand Coulee. Opening from the canyon of the Columbia in the northeastern corner of Grant County, it extends southwestward 40 miles across the plateau to the northern margin of Quincy Valley. (See Pl. XIII.) Throughout the greater part of this distance it is a wide flat-bottomed canyon walled by cliffs of basalt. The bottom of the coulee contains a series of shallow lakes.

There is abundant evidence that the Grand Coulee is an abandoned channel of Columbia River. In the glacial epoch the northern part of the State was occupied by the Okanogan ice sheet and a lobe of that glacier extended across the canyon of Columbia River upon the Waterville Plateau. Deflected by this great ice dam, the waters of the Columbia flowed along the eastern face of the glacier, cut a deep gorge, formed a cataract 400 feet high just below the site of Coulee City, and, continuing southward, discharged into Quincy Valley: In this basin during at least the early part of the glacial epoch the waters carried by Grand Coulee formed a large lake, from which they were probably returned to the valley of Columbia River over cataracts at Frenchman Springs and the "Pot Holes" southwest of Quincy. Iater they found an outlet, now occupied by lower Crab Creek, through the Frenchman Hills. This abandoned channel of 
the Columbia was described by Symons ${ }^{1}$ in 1882 and by Russell ${ }^{2}$ in 1893; the abandoned cataract which it contained was seen by Russell, and both Symons and Russell made vague references to a very large Pleistocene lake, which Symons called Lake Lewis. The abandoned channel and cataract were also described by. Calkins ${ }^{3}$ in 1905 .

\section{SURFACE OF THE BASIN.}

\section{ELEVATION.}

The floor of Quincy Valley is a nearly smooth plain, which is highest along its northern and western borders and slopes gently toward the south and east. Most of the plain lies between 1,200 and 1,300 feet above sea level. The highest points are in Babcock Ridge, a smooth, gentle swell rising to an elevation of 1,600 feet, at the rim. of the Columbia gorge; the lowest are in the sand-dune area south of Moses Lake, where the general elevation ranges from 950 to 1,000 feet.

\section{DRAINAGE.}

Crab Creek, the principal stream in Quincy Valley, rises in several branches in the vicinity of Davenport, Wash., at an elevation of about 2,500 feet. It flows at first southwestward and then westward as far as Adrian, whence it continues in a general southeasterly direction to the head of Parker Horn, a long, narrow arm of Moses Lake (see Pl. XIII); this stretch of the stream is known as upper Crab Creek. Along the greater part of the stretch above the mouth of Wilson Creek the flow is perennial; below Wilson Creek it is intermittent, the water sinking in some places and emerging from the gravel in others. During spring freshets there is a continuous flow, which for short periods may become very large.

Moses Lake is about 13 miles long and from one-half to threefourths mile in average width. In 1916 the elevation of the water surface was 1,046 feet above sea level. The lake is comparatively shallow, the maximum depth as a rule not exceeding 35 feet.

From the west side of Moses Lake, about 2 miles north of its lower end, a shallow, meandering channel leads westward and then southeastward across the sand-dune area. About 5 miles south of the lake this channel enters a coulee which cuts through the Frenchman Hills,

\footnotetext{
1 Symons, T. W., Report of an examination of the upper Columbia River : 47 th Cong., 1st sess., S. Ex. Doc. 186, 1882.

2 Russell, I. C., A geological reconnaissance in central Washington; U. S. Geol. Survey Bull. 108, 1893.

${ }^{3}$ Calkins, F. C., Geology and water resources of a portion of east-central Washington : U. S. Geol. Survey Water-Supply · Paper 118, 1905.
} 
and, continuing in a southerly direction to a point about 15 miles south of Moses Lake, it opens into a broad-bottomed, steep-walled canyon which extends westward along the north side of Saddle Mountain to Columbia River. This drainage course, through which the overflow from Moses Lake finds its way into the Columbia, is known as lower Crab Creek.

Lower Crab Creek receives contributions of water from the overflow of Moses Lake, from seepage of ground water, and in small amounts from several coulees that discharge into it from the east. In its lower course the water sinks and ordinarily no surface water is delivered to the Columbia.

Besides the surface water that enters Moses Lake by way of the channel opening into Parker Horn, considerable underflow enters the upper part of the lake or emerges as a large spring at the head of Rocky Ford Creek, which discharges into the lake.

In the western part of the basin a narrow belt of country contiguous to the gorge of the Columbia drains westward toward the river. This drainage reaches the river through a number of small gullies that head a short distance out on the plain and lead to cuts in the basalt rim rock. The gullies are dry except during rapid thaws or periods of heavy rain.

Large areas in the central and southern parts of the basin are covered by deposits formed by the wind. In these areas the gentle slopes, the porous soil, and the constant shifting of the sand prevent the establishment of any permanent drainage system. The precipitation on these surfaces either sinks into the soil immediately or gathers in undrained hollows which have been scooped out by the wind and from which it escapes by seepage or evaporation.

\section{FEATURES PRODUCED BY WIND.}

The agent which at present is most active in modifying the surface of the basin is the wind. In the northern and western parts of the basin the wind has effected only slight changes in the shape of the surface, but the results of wind work are abundantly shown in the sand drifts along the fences bordering the roads, where the soil has been stirred up by traffic, and in the sand ripples in the plowed fields. In the sandy areas of the central and southern parts of the basin the effects of wind work are more pronounced, and are most conspicuous in the sand-dune area south and southwest of Moses Lake, where the surface is thickly covered with sand dunes interspersed with undrained depressions. Many of the dunes are 40 to 50 feet high and one-fourth to one-half mile long, and in places chains of dunes extend for miles across the area. 
Where the sand for building the dunes has been excavated by the wind, there are shallow undrained basins, most of which are elliptical and which range in area from a few acres to more than 100 acres. In that part of the sand-dune area locally known as the "Pot Holes" many of these basins contain ponds of water bordered by narrow strips of meadow. Because of constant evaporation from the ponds the water is somewhat alkaline and the surrounding meadows are covered by a thick growth of salt grass and by alkali crusts. Tules and other water-loving plants grow in the ponds, and willows are common on the lee side of the dunes adjacent to the ponds.

In the sand-dune area the drainage courses have been greatly changed by the shifting sands. Thus Moses Lake owes its origin to the damming of Crab Creek by wind-blown sand.

\section{FEATURES PRODUCED BY STREAMS.}

The topography of the eastern part of the basin on both sides of Moses Lake, from Ephrata and Soap Lake to the sand-dune area, is largely the result of stream work. During the glacial epoch a great mass of gravel was discharged from the mouth of Grand Coulee and was spread in a sheet over the eastern part of Quincy Valley, completely obliterating the preexistent drainage lines and surface irregularities. As the glacial floods subsided the streams cut into the material thus laid down, and, with variations in the amount of runoff and temporary halts in the down-cutting process, produced gravel terraces separated by wide, flat-bottomed channels by which the present drainage is largely determined. Hiawatha Valley and Ephrata Valley are ancient stream valleys of this kind. Moses Lake occupies a similar ancient stream channel which was modified by wind-blown sand. From the water's edge steep banks rise abruptly to gravel terraces which occur at various heights up to 100 feet above the lake.

\section{CLIMATE.}

The "Big Bend country," embracing Douglas, Grant, Lincoln, and Adams counties, is recognized as the most arid part of the State of Washington. The average annual precipitation in this region, so far as the records show, ranges from 7 inches in the southern part to about 14 inches in the northern part. Temperatures exceeding $100^{\circ}$ above zero in summer and $15^{\circ}$ below zero in winter are not unusual, but owing to the dryness of the air the summer heat is seldom very oppressive and the cold of winter causes less suffering than in a more humid climate.

Summarized data regarding precipitation in Quincy. Valley and the surrounding region are presented in the following table: 
Mean monthly and annual precipitation, in inches, in Quincy Valley and adjacent region.

\begin{tabular}{|c|c|c|c|c|c|c|c|c|c|c|c|c|c|c|c|}
\hline Station. & $\begin{array}{c}\text { Eleva- } \\
\text { tion } \\
\text { above } \\
\text { sea } \\
\text { level. }\end{array}$ & $\begin{array}{c}\text { Length } \\
\text { of } \\
\text { record. }\end{array}$ & Jan. & Feb. & Mar. & Apr. 1 & May. & June. & July. & Aug. $\mid$ S & Sept. & Oct. & Nov. & Dec. & $\begin{array}{c}\text { An- } \\
\text { nual. }\end{array}$ \\
\hline $\begin{array}{l}\text { Waterville..... } \\
\text { Wilbur........ } \\
\text { Ritzville....... } \\
\text { Ephrata...... } \\
\text { McConihe..... } \\
\text { Trinidad....... } \\
\text { Wahluke } . . . .\end{array}$ & $\begin{array}{c}\text { Feet. } \\
2,624 \\
2,203 \\
1,825 \\
1,265 \\
1,072 \\
990 \\
410\end{array}$ & \begin{tabular}{|r|} 
Years. \\
$a$ \\
$b 20$ \\
$c 20$ \\
$c 18$ \\
$d 10$ \\
$e 5$ \\
$f 8$ \\
$g 13$
\end{tabular} & \begin{tabular}{r|}
1.67 \\
1.78 \\
1.28 \\
.96 \\
.82 \\
1.63 \\
1.17
\end{tabular} & $\begin{array}{r}1.39 \\
1.31 \\
1.39 \\
.68 \\
.75 \\
1.15 \\
.75\end{array}$ & $\begin{array}{r}0.96 \\
.78 \\
.80 \\
.54 \\
.33 \\
.52 \\
.51\end{array}$ & $\begin{array}{r}0.79 \\
.79 \\
.56 \\
.29 \\
.38 \\
.34 \\
.24\end{array}$ & $\begin{array}{r}1.26 \\
1.62 \\
.94 \\
.78 \\
.59 \\
.55 \\
.45\end{array}$ & \begin{tabular}{|c|}
0.93 \\
1.07 \\
.69 \\
.86 \\
.61 \\
.66 \\
.54
\end{tabular} & $\mid \begin{array}{l}0.47 \\
.57 \\
.27 \\
.25 \\
.37 \\
.29 \\
.33\end{array}$ & $\begin{array}{r}0.05 \\
.58 \\
.26 \\
.70 \\
.44 \\
.15 \\
.37\end{array}$ & $\left|\begin{array}{r}0.55 \\
.62 \\
.47 \\
.47 \\
.19 \\
.44 \\
.25\end{array}\right|$ & $\begin{array}{r}0.77 \\
1.10 \\
.64 \\
.77 \\
.90 \\
.52 \\
.69\end{array}$ & $\begin{array}{r}1.63 \\
1.86 \\
1.61 \\
.75 \\
1.10 \\
1.39 \\
.93\end{array}$ & \begin{tabular}{|c|}
1.92 \\
1.67 \\
1.62 \\
.92 \\
.88 \\
1.32 \\
.89
\end{tabular} & $\begin{array}{r}12.84 \\
13.75 \\
10.53 \\
7.97 \\
7.36 \\
8.95 \\
7.12\end{array}$ \\
\hline
\end{tabular}

a Partial records for years $1890,1892,1908,1909,1910,1911,1913,1914$, and 1916 included.

b Partial records for years 1892, 1898, 1899, 1900, 1907, 1909, and 1916 included. No record for years 1893 to 1897 .

c Partial records for years 1899, 1900, 1902, 1903, 1905, 1906, 1907, and 1910 to 1916 included.

$d$ Partial records for years 1903, 1905, and 1907 to 1912. No records for years 1913 to 1916.

e Partial record for 1916.

$f$ Partial records for years 1909 and 1916.

$g$ Partial records for years 1904, 1911, 1913, and 1916.

'The mean annual precipitation in Quincy Valley, according to the records from Ephrata and McConihe, ${ }^{1}$ is between 7 and 8 inches. In the region north and east of the basin the precipitation increases with increase in elevation, as is shown by the table.

Much of the winter precipitation is snow, which usually remains on the ground only a few weeks after each fall, but as it generally comes in periods of severe cold it forms a protective blanket that prevents plants from freezing. In melting it supplies moisture slowly enough to be absorbed by the fine deep soils of parts of the valley.

Because of the lower elevation of Quincy Valley, the winters are somewhat milder than in most parts of the adjacent region, and the frost-free season is longer. This is an important factor in the growing of fruit. The large number of clear suriny days is also an important factor in the ripening and coloring of fruits in this region. ${ }^{2}$

\section{SOIL AND VEGETATION.}

Before 1900 practically the only settlers in the basin were a few stockmen who had selected lands along Crab Creek and Moses Lake, chiefly because of the ready water supply, but also because of the good pasturage on the Crab Creek bottoms and among the sand dunes south of Moses Lake.

After 1900, other settlers, favorably impressed with the soil and general aspect of the country and influenced by the success of wheat farmers on the Waterville Plateau to the north, came into Quincy. Valley to raise wheat. Most of the early wheat growers settled in the northwestern part of the basin where the conditions for raising wheat are the most favorable, and as some of the first crops were

1 McConihe is a station near the head of Moses Lake (sec. 28, T. 20 N., R. 27 E.).

2 Saunders, E. J., Soil survey of Quincy area : U. S. Dept. Agr. Bur. Solls Field Operations, 1911, p. 12. 
exceptionally good, Quincy Valley was heralded as a newly discovered wheat region. The result was a great influx of settlers into all parts of the basin and within a few years practically all the public land was taken as homesteads.

At present (1917) only the lands in the vicinity of Quincy, on Babcock Ridge west of Quincy, and in the region extending southward from Quincy, are used regularly for growing wheat. In a season of average rainfall the wheat crop averages about 8 to 10 bushels per acre, ${ }^{1}$ and in exceptionally favorable seasons 25 to 30 bushels per acre has been reported. Because of the higher elevation and somewhat greater precipitation the wheat lands on Babcock Ridge yield the best crops.

But the lands in a large part of the basin proved unsuitable for raising wheat, and many of the settlers, discouraged by repeated crop failures, abandoned their claims or stayed only long enough to obtain title. Some tracts which would not produce wheat were found, however, to yield fair crops of plants more resistant to drought, such as rye, corn, and Sudan grass. In most seasons these crops do not mature sufficiently to produce marketable grain, but they make good winter feed, which is sometimes sold locally but is more often fed to the stock on the farm. Thus by feeding the farm products and utilizing the open range, or, in other words, combining farming with stock raising on a small scale, many of the settlers have managed to get along very well.

Large tracts, including the region covered by drifting sand, chiefly in the southern part of the basin, and the stony areas in the northeastern part, are entirely uncultivated, for many original settlers on these lands soon found them worthless without irrigation and consequently abandoned most of them. The uncultivated areas are used for grazing by resident stockmen and by sheepmen who are forced to bring their flocks out of the mountains at the beginning of winter. Except for short periods during the winter, when deep snow is on the ground, cattle and sheep subsist on the native sagebrush and bunch grass. Four or five weeks of feeding, in the aggregate, usually suffice to carry stock through the winter. Rye hay, corn fodder, alfalfa hay, Sudan grass, and straw are generally used for winter feeding.

The report on Quincy Valley by Mangum, Van Duyne, and Westover, ${ }^{1}$ published by the United States Department of Agriculture, contains a full discussion of the various types of soil in the valley and their value for agriculture, and includes also a detailed map showing the areas covered by the soils of various types.

1 Mangum, A. W., Van Duyne, Cornelius, and Westover, H. L., Soll survey of the Quincy area, Waş,; U. S. Dept. Agr. Bur. Soils Field Operations, 1911 (Advance sheets), p. 17, 1913, 


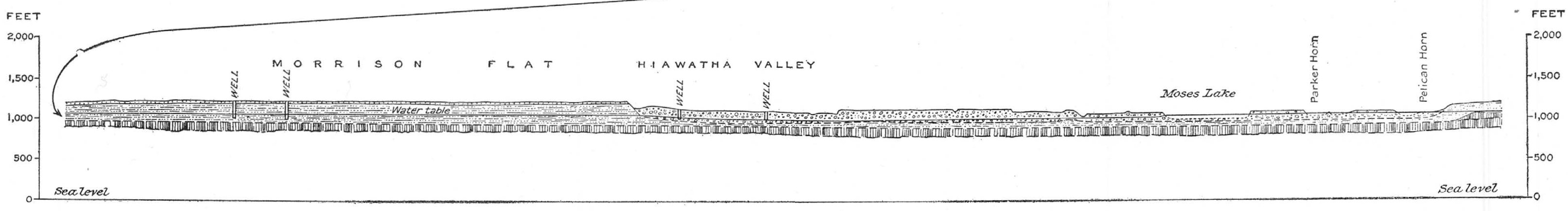

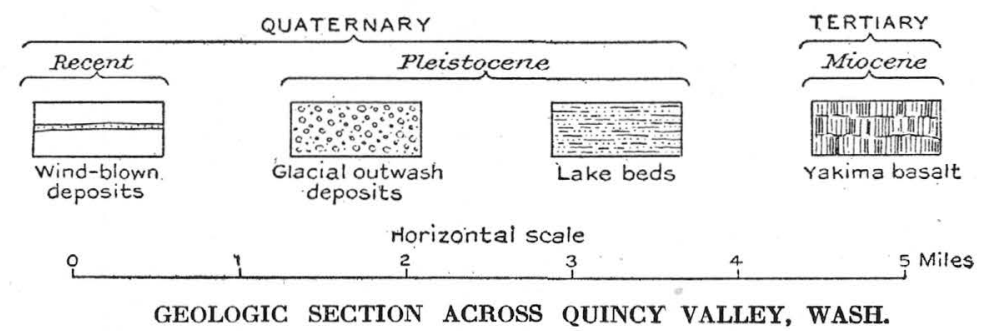

GEOLOGIC SECTION ACROSS QUINCY VALLEY, WASH. 


\section{GEOLOGY.}

\section{GENERAI FEATURES.}

Quincy Valley lies within the vast area which in Miocene time was inundated by great floods of basaltic lava. Though covered in most places by sedimentary deposits, the basalt nowhere in the basin is very far beneath the surface. The great thickness of the basalt series is well shown in the gorge of the Columbia, which has been cut into the basalt to a depth exceeding 800 feet without exposing the underlying rocks.

The sedimentary deposits overlying the basalt consist of unconsolidated beds of clay, sand, and gravel derived from the Okanogan glacier, which occupied the Waterville Plateau in the Pleistocene epoch and discharged its débris-laden floods into Quincy Valley through the Grand Coulee. (See Pl. XIII.) Some of these deposits were laid down in the quiet waters of anlake; others were laid down by streams. Overlying the basalt, the lake beds, and, in some places, the stream deposits is a mantle of wind-blown sand and silt. (See fig. 6 and geologic section, Pl. XIV.)

\begin{tabular}{|c|c|c|c|c|c|c|}
\hline System. & Series. & Formation. & Section. & $\begin{array}{l}\text { Thick- } \\
\text { ness in } \\
\text { feet. }\end{array}$ & $\begin{array}{l}\text { Character of forma- } \\
\text { tion. }\end{array}$ & $\begin{array}{l}\text { Character of topog- } \\
\text { raphy and soil. }\end{array}$ \\
\hline & R ecent. & $\begin{array}{l}\text { Wind - blown } \\
\text { deposits. }\end{array}$ & & 50 & $\begin{array}{l}\text { Wind-blown silt and } \\
\text { sand. }\end{array}$ & $\begin{array}{l}\text { Level plains and sand } \\
\text { dunes. Soil rang- } \\
\text { ing from silty loam } \\
\text { to dune sand. }\end{array}$ \\
\hline : & & $\begin{array}{l}\text { Glacial-out- } \\
\text { wash depos- } \\
\text { its. } \\
\text {-Unconformity-- }\end{array}$ & 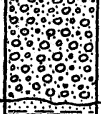 & 90 & $\begin{array}{l}\text { Stratified sand, } \\
\text { gravel, and boul- } \\
\text { ders. }\end{array}$ & $\begin{array}{l}\text { Terraces and broad, } \\
\text { shallow channels. } \\
\text { Gravelly soil. }\end{array}$ \\
\hline $\begin{array}{c}\text { Quater- } \\
\text { nary. }\end{array}$ & $\begin{array}{c}\text { Pleisto- } \\
\text { cene. }\end{array}$ & Lake beds. & 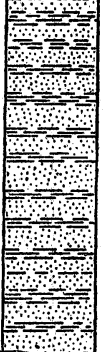 & 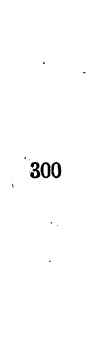 & $\begin{array}{l}\text { Stratified clay and } \\
\text { sand with local } \\
\text { beds of gravel and } \\
\text { boulders. }\end{array}$ & $\begin{array}{l}\text { No natural exposures } \\
\text { except in a few } \\
\text { places on the faces } \\
\text { of terraces and in } \\
\text { small areas where } \\
\text { soil has been re- } \\
\text { moved by winds. } \\
\end{array}$ \\
\hline $\begin{array}{l}\text { Ter- } \\
\text { tiary. }\end{array}$ & $\begin{array}{l}\text { Mio- } \\
\text { cene. }\end{array}$ & Yakima basalt. & 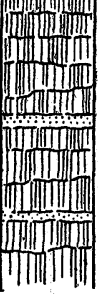 & $1,300 \pm$ & $\begin{array}{c}\text { Basalt with a few } \\
\text { thin beds of tuff. }\end{array}$ & $\begin{array}{l}\text { Rough, broken areas } \\
\text { and precipitous clifis. }\end{array}$ \\
\hline
\end{tabular}

FIGURE 6.-Generalized columnar section of geologic formations in Quincy Valley, Wash. $74351^{\circ}-19-\mathrm{wsP} 425-10$ 
YAKIMA BASALT.

The basalt of Quincy Valley, in its typical development, is a hard, dense, fine-grained rock, varying in color from dark gray to black, except on weathered surfaces, where it is usually brownish. The lava that formed the basalt was not all poured out at one time but was a series of flows, and each bed represents a distinct extrusion. The texture of the basalt shows considerable variation. At the upper surface of a bed the rock is usually scoriaceous, or "honeycombed," because of the expansion and escape of the dissolved gases in the lava, but the rock becomes increasingly dense toward the interior of the flow.

By the characteristic "honeycombed" structure the individual lava flows can be identified, and different flows can be distinguished from one another. In the gorge of the Columbia, where the basalt underlying Quincy Valley is exposed, six or eight different flows can be identified. The individual beds are usually not more than 50 to 150 feet thick, but their lateral extent is great, for their edges may be traced for miles along the canyon walls without any evidence of thinning out. At a few places thin beds of tuff, or volcanic ash, are interbedded with the massive basalt, but their volume is insignificant in comparison with the great volume of the basalt.

A characteristic and almost universal feature of the basalt is the system of joints perpendicular to the bedding planes, by which the sheets are broken into prismatic columns as a result of contraction in the process of cooling. This columnar jointing is splendidly displayed in the palisades of the Columbia gorge and the great coulees.

Structurally Quincy Valley is a shallow basin. At the rim of the Columbia gorge the beds of basalt dip eastward at an angle of $1^{\circ}$ or $2^{\circ}$. Farther east the beds gradually flatten out and then rise again with a gentle inclination east of the valley. To the north the beds rise rather steeply to the Badger Hills, and to the south they are upturned to form the Frenchman Hills. The dips do not represent the original position of the beds but are due chiefly to gentle warping at some time since the deposition of the basalt.

Normally the basalt is compact and contains almost no pores capable of transmitting water. The ability of the basalt to absorb and store large quantities of water is due to the zones of porous rock between the successive beds and to the joints by which the beds are broken. Although the porous contact zones are generally thin and irregular, in many places they are thick, and, in connection with communicating passages produced by vertical and horizontal joints,

1 This name was first used by Geo. Otis Smith in Water-Supply Paper 55 to differentiate the basalt of Miocene age from the older and younger basalt formations included in the general term Columbia River lava as used by I. C. Russell. F. C. Calkins, in Water-Supply Paper 118, mapped the basalt of Quincy Valley as Yakima basalt, and later maps correlate the basalt of this area with the typical Yakima basalt. 
they form a circulating system through which water may travel for long distances.

\section{IAKE BEDS.}

\section{CHARACTER AND DISTRIBUTION.}

Lying upon the surface of the basalt are sedimentary deposits consisting of a series of stratified clay, sand, and gravel, which there is good reason to believe were laid down in impounded waters. The deposits are rarely exposed at the surface but are shown by well records to be widely distributed and continuous over nearly all parts of Quincy Valley. In the western, central, and southern parts of the basin the formation is covered by wind-deposited soils and drifting sands, and in the eastern part by glacial gravel. (See geologic section, Pl. XIV.)

Along the rim of the Columbia gorge the lake beds are absent and the basalt outcrops at the surface. In most of the western and northwestern parts of the valley they are not more than 30 to 40 feet thick, but they thicken eastward, and wells on Morrison Flat penetrate nearly 300 feet without reaching the basalt. In the eastern part of the basin the upper 150 to 200 feet of the series has been removed by stream erosion and replaced by a thick covering of glacial stream deposits.

No complete section of the lake beds is exposed anywhere in the area, but as encountered in wells the beds consist of a series of alternating beds of clay, silt, and sand, and occasionally a layer of gravel. The clays are light gray, greenish gray, blue, or black, and are generally heavy and compact, but are in places of light weight and open texture because of an admixture of volcanic ash. Some of the darkcolored clays contain large amounts of organic matter, a fact that probably accounts for the foul odor and gas reported from some wells that penetrate the clays. Petrified wood and bones and fossil shells are found in the clays. The coarser materials of the lake deposits are of all grades, ranging from light-colored silt and very fine sand to beds of coarse boulders.

\section{ORIGIN AND AGE.}

The topography of the basin, the regular stratification of the sediments, the presence of fossils, and the widespread occurrence of erratic boulders are evidences that the valley was at one time occupied by a lake. This subject will be more fully discussed in the final report. To create a lake in the valley at the present time all that would be necessary, providing the run-off were sufficient, would be to block the gap where lower Crab Creek passes through the Frenchman Hills. 
W. H. Dall states that the fossils collected from the lake beds are fresh-water species, all of which are still living and are not older than the Quaternary period. They are of the boreal type and could have lived in the cold water of a glacial lake.

\section{GLACIAI OUTWASH.}

\section{DISTRIBUTION AND CHARACTER.}

Deposits of glacial outwash cover a large area extending from the mouth of Grand Coulee, past Ephrata, and southward into the Moses Lake region and Hiawatha Valley. They consist mostly of fragments of basalt, but other rocks, chiefly granite, are sparsely represented. The materials are fairly well assorted, ranging in coarseness from sand to large boulders.

Near Soap Lake and Ephrata these deposits lie directly on the basalt, but farther south, in the vicinity of Moses Lake and in Hiawatha Valley, they lie on the lake beds. Having been deposited on an uneven surface, the formation varies in thickness from place to place; its greatest known thickness, as shown by well records, is about 90 feet.

\section{ORIGIN AND AGE.}

The outwash deposits were derived from the same source as the lake beds - that is, they were laid down by the débris-laden floods that were discharged through Grand Coulee from the Okanogan glacier in the Pleistocene epoch. Most of the material forming the higher terraces near the mouth of Grand Coulee was probably deposited at the same time that the fine sediments were being laid down in the glacial lake. The sudden lessening of the velocity of the flood waters as they emerged from Grand Coulee and spread out over the plain and the consequent decrease in their carrying power caused the coarse material to be deposited near the mouth of the canyon while the finer sediments were carried into the lake.

The lowering of the lake outlet did not cease with the draining of the lake but continued below the floor of the lake, the result being that in the eastern part of the basin the upper part of the lake beds and much of the previously deposited outwash material was removed, and the general level of this part of the valley was reduced. Later more outwash material was deposited on the eroded surface and the region was built up to its present general level. Neither deposition nor erosion, however, was continuous, for the glacial streams alternately cut channels and then refilled them with gravel, and these successive episodes are recorded in the terraces of the region. 


\section{WIND-BLOWN DEPOSITS.}

Overlying the basalt, the lake beds, and, in some places, the glacial outwash deposits, is a thin mantle of wind-blown material consisting of fragments ranging in size from very fine silt to coarse sand. Except for the gravelly soils of the eastern part of the basin and the residual soils in the areas of outcropping basalt along the edge of the Columbia gorge, practically all the soils of the basin are composed of wind-blown materials, which also extend beyond the boundaries of the basin and cover the Frenchman Hills and the plain south of the hills. North of the basin wind-blown soils are found on the Badger Hills and the Waterville plateau. The wind-blown deposits of Quincy Valley are derived from the fine sediments deposited in the glacial lake. Under the prevailing arid climate these dry, loose-textured materials, only slightly protected by the meager vegetation, are easily moved about by the high winds, which at certain times of the year occur with great frequency. In the western part of the basin, where the soils are of very fine texture, the winds have produced only minor irregularities of the surface, but farther east, where the sands are coarser, the effect of the wind is much more conspicuous, and sand dunes are familiar features.

\section{WATER TABLE.}

\section{DEPTH TO WATER.}

The depth to water in Quincy Valley was ascertained at about 250 widely distributed points, at most of which it was accurately measured in wells. Where measurement was not possible, reports were obtained from well owners, drillers, and other reliable persons. In general the depth to water varies with the elevation of the land surface, the water being nearest the surface in the low areas and the depth increasing progressively with increase in altitude.

In a part of the sand-dune area southwest of Moses Lake the ground water comes to the surface in many springs and collects in depressions among the dunes, forming small ponds and marshy tracts. Extending northward from this area to the vicinity of Mae and westward along the foot of the Frenchman Hills to a point nearly 20 miles west of Crab Creek, and including a large part of the dune area, is an extensive region in which water is less than 50 feet below the surface. Smaller areas outside of the dune area in which the ground water is within 50 feet of the surface include a part of Hiawatha Valley, the lowest terraces bordering Moses Lake, the bottom lands along Rocky Ford Creek, and strips of land on both sides of upper Crab Creek in its lower course, where it is locally known as Willow Creek. 
The depth to water ranges from 50 to 100 feet throughout much of the sandy country in the south-central part of the basin, including the district near Bailey and that south of Morrison Flat. Other areas where the depth to water ranges between 50 and 100 feet include most of Hiawatha Valley, terraces of intermediate height in the vicinity of Moses Lake, and the lower terraces around Ephrata, Soap Lake, and Adrian.

The depth to water ranges from 100 to 150 feet in a large area in the west-central part of the basin extending westward from Morrison Flat and northward from Low Gap almost to Winchester. Other areas where water is found at these depths include the highest terraces in the Moses Lake region, the highest parts of the interstream areas extending from Ephrata to the vicinity of Moses Lake, and large parts of the upland surface east of Moses Lake and upper Crab Creek.

The depth to water is 150 to 200 feet throughout Morrison Flat, south of the Great Northern Railway, in the immediate vicinity of Winchester, and in a belt about 4 miles wide extending from Winchester to Burke.

\section{FORII OF THE WATER TABLE.}

Near Quincy, in most of the area south and west of Quincy, and in a belt north of the railroad near Winchester the depth to water ranges from 150 to 300 feet.

The position of the water table, or upper surface of the zone of saturation, is shown with respect to sea level by contours on Plate XIII. West of the steep slope that extends along the east side of Morrison Flat from within 4 or 5 miles of Ephrata almost to the Frenchman Hills the water table is nearly level or only slightly inclined, except along the north edge of the basin, where it rises toward the Badger Hills, and along the west edge, where it drops abruptly in the direction of the Columbia gorge. The elevation of the water table throughout this area, according to accurate determinations made at a large number of points, is about 1,080 feet above sea level. East of this steep slope the water table descends rapidly to a minimum level of about 1,000 feet above the sea.

In the eastern province the water table descends at a fairly uniform rate from the north to Moses Lake (altitude, 1,046 feet) with the surface of which it coincides. On the west side of the south part of Moses Lake the water table descends abruptly from the lake level to an elevation of only 1,030 feet above sea level in Hiawatha Valley and the vicinity of Mae. Thence, it declines more gradually southward to a level of about 1,000 feet in the sand-dune area, where it comes to the surface in many places and coincides with the surfaces of the ponds. 


\section{WATER-BEARING FORMATIONS.}

WATER IN BASALT.

The basalt underlying Quincy. Valley consists of a series of beds, each of which represents a separate flow. The upper crust of a lava sheet generally has a vesicular or "honeycombed" structure, caused by the escape of steam and other gases from the molten lava, and its upper surface is generally rough and broken, owing to sudden chilling of the lava. Consequently many openings, some of which are extensive, occur between the successive beds, and these are capable of holding much water. In some places the successive beds are separated by beds of tuff and other volcanic fragmental material, but these interbedded deposits are of small volume and almost impervious, and consequently furnish little storage space for water. The interior of a bed, formed of a lava that cooled gradually, is usually fine grained and compact, but in the process of cooling there was much contraction, so that joints and fissures which provide for the storage and circulation of water were formed throughout the mass. The total capacity of the basalt formation for water is therefore rather large.

In the western part of the basin, including the region around Quincy, Burke, and Winchester, and north of the railroad between Winchester and Ephrata, almost all the wells obtain their water from the basalt. Near Quincy and Winchester large supplies are obtained for irrigation. A number of wells yield between 250 and 500 gallons per minute and one well near Quincy produces between 900 and 1,000 gallons per minute under continuous pumping. Near the rim of the Columbia gorge some wells have failed to obtain adequate supplies, but throughout the rest of the region failures are rare. Most of the large yields of water are obtained from beds of the "honeycombed" texture found between layers of compact material. A few of them come from the massive basalt.

The water in the basalt is derived from that which falls on the basin and percolates downward and from that which has been absorbed by the basalt outside of the basin and has traveled laterally underground perhaps for a long distance. In the western part of the basin, where the materials overlying the basalt are dry, most of the water that falls as rain or snow does not get far below the surface. This statement in especially true of the precipitation in the areas overlain by fine silty soils. - Where the basalt is at or near the surface or where the sediments above the basalt consist of gravel or coarse sand the precipitated water sinks more rapidly below the reach of evaporation and transpiration, and a larger proportion reaches the water table. The numerous undrained basins are also favorable to 
intake of water. If the average annual precipitation over an area of 300 square miles in the western and central parts of the basin west of the sag in the water table shown in Plate XIII is $7 \frac{1}{2}$ inches, and 10 per cent of this precipitation reaches the water table, the average annual underground supply from this source is about 12,000 acre-feet.

The structure of Quincy Valley, determined by the lava beds that dip toward it from all directions, is favorable for the accumulation of ground water under the basin, but, on the other hand, the gorge of the Columbia, and, to a less extent, Moses Coulee and other deep coulees, are very unfavorable.

The map (Pl. XIII) shows that the water table is highest along the northern border of the basin. As water underground, like water at the surface, is highest near its source, this map indicates that one of the main sources of supply is the plateau north of the basin. The basalt beds out of which the plateau is built dip southward, and water which falls on the plateau may be led down the dipping strata beneath Quincy Valley. The plateau lies considerably higher than the basin and receives more abundant precipitation. As it is a surface of extensive erosion in which porous beds of the basalt formation are exposed, much of the rain and snow which it receives may be absorbed by the rocks.

Some parts of the plateau are, however, so deeply dissected as to diminish its efficacy as an intake area. Lynch, Moses, and Grand coulees (see Pl. XIII) are cut many hundreds of feet into the basalt, and the porous beds are exposed to leakage along the walls of the coulees. Where the coulees cut the water-bearing beds that underlie Quincy Valley and extend down to the level of the water table beneath the basin they effectively bar the movement of ground water into the basin and constitute definite outer limits for the areas contributing ground water. The contributory area on the north is therefore limited by Lynch, Moses, and Grand coulees, but between Moses Coulee and Grand Coulee there is no impassable barrier to the migration of ground water. (See Pl. XIII:)

That there is not very ready movement through the basalt laterally is indicated by the nearly level position of the water table over the greater part of the basin and by its abrupt downward slope, especially on the west side of this level area. The contributory area on the north probably does not include more than 300 square miles. The average annual precipitation on this area is about 15 inches. If 5 per cent of this precipitation is absorbed and migrates to Quincy Valley, the annual contribution is about 12,000 acre-feet.

West of Quincy Valley the gorge of Columbia River extends far below the level of the water table of the deepest water-bearing bed that has been reached by wells in the basin. There is therefore no contribution from the west. The loss of water from the basalt beds 
at the outcrops is, however, not so great as might be expected, as is shown by the form of the water table (Pl. XIII), by the large yields of wells situated within a few miles of the gorge of Columbia River, and by the scarcity of large springs along the gorge. The retention of the water in the reservoirs of basalt is probably due both to the eastward dip of the beds and to a general lack of lateral communication between the cavities in the basalt.

There is an erroneous belief among some of the inhabitants of Quincy Valley that the water in the basalt comes from Lake Chelan, because the water table throughout most of the western and central parts of the basin stands at practically the same level as the lakeabout 1,080 feet above sea level. It is obvious that no water can be derived from this source because of the existence of the intervening Columbia gorge, which is cut several hundred feet below the level of the Iake, and below the water table of Quincy Valley, and is also cut through the water-bearing beds tapped by the wells in the basin.

That no large supply is received from the region south of Quincy Valley is shown by the water levels in the southern part of the basin and by the structure and topography of the region to the south. The northern limb of the anticline that forms the Frenchman Hills is narrow and the area south of these hills is deeply dissected.

East of Quincy Valley is an extensive area that slopes toward the basin and is underlain by beds of basalt that dip toward and extend beneath the basin. These beds no doubt deliver water in the general direction of the basin. On account of the sag in the surface and in the water table in the eastern part of the basin (Pl. XIII) this water probably does not reach the central and western parts of the basin but leaks into the sediments that overlie the basalt in the eastern part. If the more impervious beds of the basalt formation are sufficiently competent as confining beds, some of the water in the underlying porous beds may be carried by artesian pressure to the central and western parts of the basin, but there is considerable evidence that such artesian movement is absent or unimportant.

It appears, therefore, that most of the water in the basalt in the western and central parts of the basin is derived from rain and snow that fall there or on the upland farther north.

In the western part of the basin artesian pressure that will lift the water in deep wells much above the water table is not to be expected because of the depressing influence of the gorge of Columbia River. In the low area adjacent to Crab Creek and Moses Lake, where the water table sags (see Pl. XIII), the water from deep basalt beds would probably rise farther above the level of the water table, and it is possible that the artesian pressure would be sufficient to bring the water to the surface in the lowest places. 
That the quantity of water stored in the basalt beneath the basin is large and that there is considerable underground circulation is shown by the fact that single wells yield 250 to 1,000 gallons a minute without diminution in the supply great enough to have been detected. The amount of water stored beneath the basin is, however, not a safe criterion by which to gage possible development of irrigation, for it may have taken centuries for this water to accumulate and the rate of inflow may be very slow. In considering the amount of water available for irrigation the quantity now stored in the rocks is not so important as the annual increment to the supply. It is evident that even though much water is stored beneath the basin, continual withdrawals in excess of replenishment will result in a gradual lowering of the water table.

Before any water was pumped there was probably a natural bal- ance between loss and gain, the leakage out of the basalt in Quincy Valley being about equal to the intake, and leakage will continue in spite of recoveries by pumping. Therefore, even if the average annual intake is as much as 24,000 acre-feet, the supply that will be available year by year is less than this amount, although by pumping out the water now in storage a much larger quantity could be obtained for a few years.

Whether the water table has been lowered by the pumping that has already been done is not precisely known. The numerous exact measurements of depths to water that have been made in connection with the present investigation, will, however, make it possible to determine very closely the effects of future pumping operations.

The conclusions regarding the water in the basalt underlying Quincy Valley may be briefly stated as follows: The quantity of water stored in the basalt is large. The conditions are such that it is impossible to estimate closely the annual intake or the amount that can be recovered annually by pumping, without drawing seriously on the reserve, but the authors believe that the annual intake of water is not more than 24,000 acre-feet, and that the quantity which can safely be pumped annually within the area in which the wells end in basalt is less than this amount. The available supply. is doubtless adequate to serve indefinitely the land now under irrigation, and experience may prove that considerably more land can be brought under irrigation. The geologic and topographic conditions make it certain, however, that it will be impossible to irrigate the entire basin with water obtained from this source, or even a large proportion of the area in which the wells end in basalt, and they also indicate that it would be unwise at present to increase the area to be irrigated with the water from the basalt by more than a few thousand acres. 


\section{WATER IN LAKE BEDS.}

Throughout the central part of the basin-on Morrison Flat and adjacent areas to the north and west and in the sandy country extending southward from Morrison Flat to the Frenchman Hills and southwestward to Bailey and Low Gap-most of the wells obtain water from the unconsolidated, fine-grained, lake beds that overlie the basalt. The material penetrated in wells in this part of the basin consists of clay and sand in alternating beds, and a few thin layers described as "lime rock" or "hardpan." Beneath these deposits basalt is found at depths ranging from less than 100 to more than 350 feet in different localities. Beds of quicksand, coarse basaltic sand, and occasionally of fine gravel that yield good supplies of water are found at intervals below the water table.

Many wells have been sunk into the lake beds, and, in so far as information was obtained, none of them have failed to get water, although a number of owners of comparatively shallow stock or domestic wells have reported "small" or "insufficient" yields. Wells that are properly constructed and are sunk deep enough to penetrate several water-bearing beds generally fulfill all requirements. Pumping plants supplying water for irrigation have been installed on Morrison Flat and in a number of other places, and single wells have been reported to yield 300 gallons per minute.

In the lake-beds area the water table is at about the same elevation as in the basalt area to the west and distinctly higher than in the area of glacial outwash to the east. It appears, therefore, that the water in the lake beds is derived from the same sources as that in the basalt and is not supplied to any important extent by Crab Creek or the glacial-outwash deposits.

\section{WATER IN GLACIAL-OUTWASH DEPOSITS.}

In the eastern part of the basin, in an area extending from Ephrata, Soap Lake, and Adrian, to the vicinity of Moses Lake and beyond, the principal water-bearing formation consists of rudely stratified deposits of waterworn and water-sorted sand, gravel, and boulders. In some places this formation lies on the lake beds, and in others it lies directly on the basalt. Owing to irregularities in the surface on which it rests and in its own upper surface its thickness is variable, ranging from only a few feet to 90 feet or more.

Being unconsolidated and containing a large proportion of coarse material, the glacial-outwash deposits allow very free circulation of water. Wells in this material yield large quantities with very little lowering of water level. In the Moses Lake region large supplies for irrigation are obtained from wells that are sunk only 2 or 3 feet below the water level. One such well was tested in connection with the present investigation-a well on the farm of George C. Hill at 
Mae. This well is $3 \frac{1}{2}$ feet square and 78 feet deep and is equipped with a 12-horsepower gasoline engine and a 3-inch horizontal centrifugal pump. At the beginning of the test, before the pump was started, the water stood 74.6 feet below the surface of the ground. When the pump was started the water level was rapidly drawn down to 74.9 feet, but was not further lowered during a 20 -minute test. The drawdown was, therefore, only 0.3 foot. The discharge as measured was 270 gallons per minute. When the pump was stopped the water level rose immediately to its normal position of 74.6 feet below the surface. Owners of many other wells in this region report equally good results.

The glacial-outwash deposits receive (1) water that falls as rain or snow on that part of Quincy Valley underlain by the outwash deposits and sinks directly into them; (2) water that falls on the extensive drainage basin of Crab Creek and is poured into Quincy Valley either as surface water or as underflow of Crab Creek; (3) water that falls on the elevated region east of Quincy Valley and south of the drainage basin of Crab Creek and is carried in freshets to the valley, where part of it sinks into the outwash deposits; (4) similar storm waters from the eastern part of the Badger Hills and the central part of Quincy Valley; (5) water from the basalt under the plateau north of the basin and from the basalt and overlying lake beds in the western and central parts of the basin, which enters the outwash deposits from the northwest or west; (6) water that falls on the region east of Quincy Valley, percolates into the underlying basalt, and moves westward toward the basin. (See Pl. XIV.) It will be seen, therefore, that the Moses Lake region of Quincy Valley forms a sort of huge trap for the water that falls on it and on a large adjacent region. The only outlets are (1) the gap of lower Crab Creek, (2) the cavities in the basalt of the Frenchman Hills, and (3) the atmosphere, which removes large quantities of water that is at or near the surface. No water is contributed from the Grand Coulee, for Soap Lake, which lies at the mouth of the coulee, never overflows, and it is separated more or less effectively from the outwash deposits of Quincy Valley by a ledge of basalt. The alkaline character of its water shows that it does not discharge by underflow.

The most important sources of water in the outwash deposits are the first two mentioned. The underflow from the west must necessarily be small. The basalt formation beneath the region east of the basin apparently dips very gently toward the basin, but it is deeply trenched by coulees that interrupt the migration of water through it. Some ground water no doubt reaches the Moses Lake region from the east through porous lava beds that are continuous beneath the coulees, but the contributions from this source are probably not large.

The movements and disposal of water from the drainage basin of upper Crab Creek is for convenience shown diagrammatically in 
figure 7. This water enters the basin partly as surface flow and partly as underflow.

The surface flow divides a short distance below Adrian, a part going southward through a channel locally known as Willow Creek into Parker Horn of Moses Lake, and the other part going westward a short distance on the north side of the Great Northern Railway into a large, shallow basin known as the Adrian Sink. In the earlier part of a flood most of the water takes the latter course, and it continues to flow in this direction until the sink is filled, after which the water goes down the channel leading into Moses Lake.

Both from Adrian Sink and from the channel leading to Moses Lake water percolates into the glacial gravels and slowly moves underground in a general southward direction. Part of this water reappears in large springs at the head of Rocky Ford Creek, and thence flows into Moses Lake. The rest moves southward through the gravels, a part seeping into Moses Lake and a part eventually reaching the surface in the springs, ponds, and swampy tracts of the sand-dune area south of the lake.

Moses Lake receives water from streams, precipitation on its surface, and under- FIGURE 7.-Diagram showing movements and disground seepage; and discharges water by surface

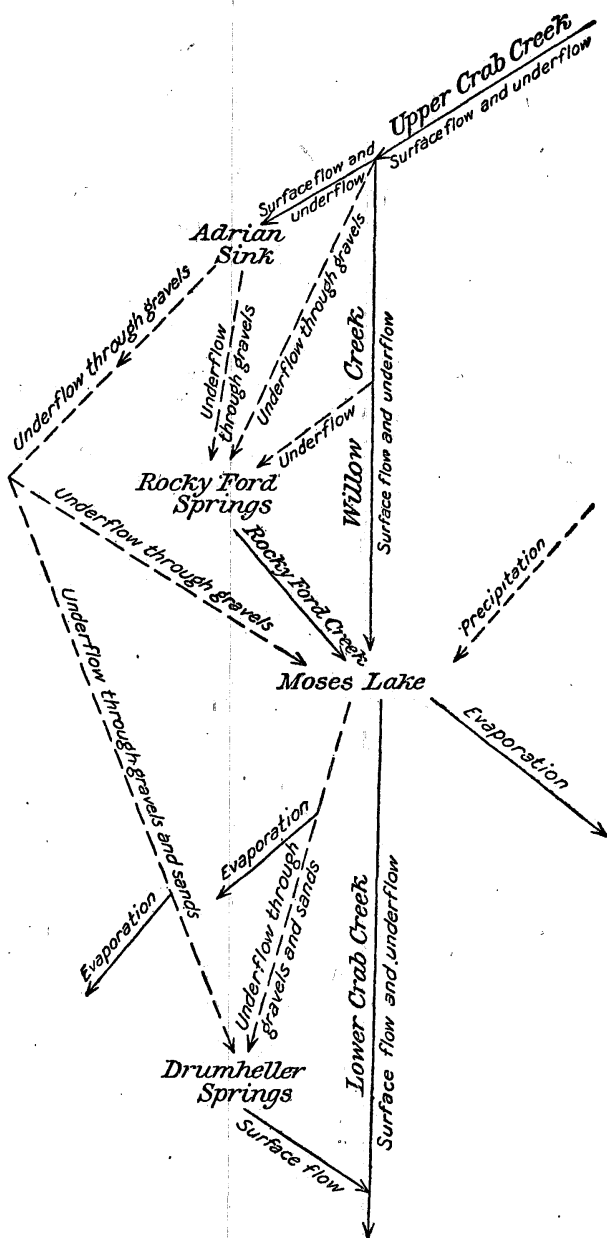
posal of surface and ground water in the Moses Lake region. of Quincy Valley, Wash. flow through its outlet, by evaporation from its surface, and by seepage through its sides and bottom. As shown by the slope of the water table toward the lake (PI. XIV), ground water enters the lake along almost its entire length on the east side and along the northern part of its west side. Similarly a slope of the water table away from the lake indicates a loss of water along the west side as 
far north as the big bend 4 miles north of Mae. In the sandy country near the south end of the lake the loss by seepage is considerable. Farther north, however, loss by seepage appears to be small in spite of the decided slope of the water table away from the lake, for water levels in wells very close to the lake are considerably below the lake level, a condition that obviously could not exist if there were any considerable seepage from the lake. The sides of the lake along this stretch are formed of gravels that differ little in texture and composition from the water-bearing gravels found in wells throughout the region. Through these gravels the water generally moves with the greatest freedom, and the comparative imperviousness of the gravels forming the lake shore must be ascribed to an extraneous cause, such as natural puddling or a sealing of the pores by silt or vegetal growth, or possibly to some extent by the precipitation of chemical substances. Much of the water that seeps out of the lake returns to the surface farther south.

The amount of water annually available from the outwash deposits is to some extent indicated by the amount that enters the area and by the amount that is discharged. Concerning the part that is added through stream flow and precipitation, approximate information is available, but the amounts entering as underflow are unknown.

The following table, compiled chiefly from measurements and estimates made by F. F. Henshaw, of the United States Geological Survey, based on stream-flow records collected by the Geological Survey and on precipitation records by the Weather Bureau, both in cooperation with the Grant Realty Co., summarizes the available data:

Additions to and losses from water supply of Moses Lake region, Quincy Valley, 1910 to 1913 , inclusive.

\begin{tabular}{|c|c|c|c|c|}
\hline & 1910 & 1911 & 1912 & 1913 \\
\hline $\begin{array}{l}\text { Flow of Crab Creek at Adrian } a \ldots \\
\text { Flow of Crab Creek at Neppel } a . . .\end{array}$ & $\begin{array}{r}\text { Acre-feet } \\
27,800 \\
19,000\end{array}$ & $\begin{array}{r}\text { Acre-feet. } \\
10,900 \\
5,000\end{array}$ & $\begin{array}{r}\text { Acre-feet. } \\
\mathbf{3}, 760 \\
0\end{array}$ & Acre-feet. \\
\hline 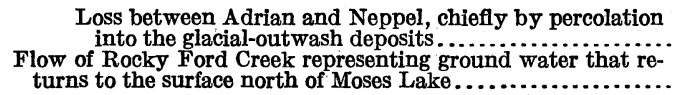 & $\begin{array}{r}8,800 \\
50,000\end{array}$ & $\begin{array}{r}5,900 \\
35,100\end{array}$ & $\begin{array}{r}3,760^{\circ} \\
38,500\end{array}$ & 42,000 \\
\hline $\begin{array}{l}\text { Evaporation from Moses Lake.... } \\
\text { Precipitation on Moses Lake..... }\end{array}$ & $\begin{array}{r}24,200 \\
3,790\end{array}$ & $\begin{array}{r}26,400 \\
3,120\end{array}$ & $\begin{array}{r}27,800 \\
4,000\end{array}$ & $\begin{array}{r}30,200 \\
3,780\end{array}$ \\
\hline 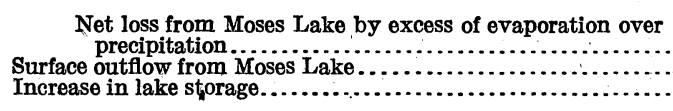 & $\begin{array}{r}20,410 \\
26,000 \\
8,510 \\
\end{array}$ & $\begin{array}{r}23,280 \\
0 \\
12,000 \\
\end{array}$ & $\begin{array}{r}23,800 \\
0 \\
10,970 \\
\end{array}$ & $\begin{array}{r}26,420 \\
22,700 \\
17,740 \\
\end{array}$ \\
\hline 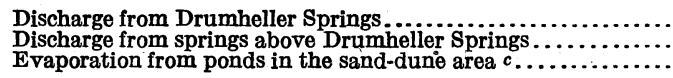 & $\begin{array}{r}13,430 \\
2,800 \\
9,200\end{array}$ & $\begin{array}{r}\mathbf{1 2 , 0 9 0} \\
3,090 \\
9,200\end{array}$ & $\begin{array}{r}b 12,000 \\
1,740 \\
9,200\end{array}$ & $\begin{array}{r}b 12,000 \\
2,300 \\
9,200\end{array}$ \\
\hline $\begin{array}{l}\text { Total ground-water discharge south of Moses Lake, exclu- } \\
\text { sive of evaporation and transpiration from swampy areas. }\end{array}$ & 25,430 & 24,380 & 22,940 & 23,500 \\
\hline
\end{tabular}
the average annual evaporation is equivalent to a depth of water of 4.6 feet, the same as for Moses Lalie. 
In the northern section of the Moses Lake region the ground-water discharge is represented by the flow of Rocky Ford Creek, the evaporation in the swampy tracts north of the lake, and the seepage into the lake. In the southern section it is represented by the flow of Drumbeller and other springs and the evaporation from the ponds and swampy tracts south of the lake. Some of the ground water discharged from the northern section no doubt passes underground a second time and is again returned to the surface in the area south of the lake. (See fig. 7, p. 153.) The total discharge amounts to some tens of thousands of acre-feet a year. Not all this water can be recovered for irrigation, for much is lost by evaporation from the surface of Moses Lake or becomes unavailable by passing into the lake at its north end and discharging at the south end into the sand-dune area, where it can not be used for irrigation. If it were not for the existence of Moses Lake the loss from the underground reservoir would be much less and the available supply would be much greater.

The supply is, however, certainly adequate for much more irrigation than is at present practiced. In view of the large contributory area and the excellent intake facilities afforded by the deposits of sand and gravel it is not probable that the demands for irrigation in the Moses Lake region will exceed the supply. It is believed that the above data show that an additional 5,000 acres can be irrigated in this region.

\section{QUALITY OF WATER.}

Analyses of samples of 13 ground waters and 6 surface waters, which were made in order to determine the quality of water in this basin, will be published in a later report. In general, these analyses indicate a very favorable condition of the ground waters. The waters represented by 11 of the samples are classed as good and 2 as fair for irrigation. Most of them are calcium-carbonate in character, only 1 containing in predominating amounts sodium and carbonate, the constituents of black alkali. Even this water, however, is good for irrigation and would not damage even the most sensitive crops, unless used in a grossly careless manner. Most of the waters are good or fair for domestic use, but two have been classed as bad, one bceause of its high mineral content, especially of calcium and magnesium, which cause hardness and excessive consumption of soap in washing, and the other because of its high content of bicarbonate.

The surface waters analyzed vary more widely in their value for irrigation and domestic use. Two samples from different points in Moses Lake show this water to be sodium-carbonate in character but sufficiently low in these and other mineral constituents to be entirely satisfactory for irrigation and for domestic use.

The water from a pothole in the NW. $\frac{1}{4}$ sec. 22 , T. 19 N., R. 25 E., was found to be fair only for domestic use and for irrigation. Soap 
Lake, Grimes Lake, and a lake in Grand Coulee, 5 miles above Coulee City, all furnish water which is too highly mineralized to be useful as domestic supplies: The waters from Soap and Grimes lakes are classed as bad for irrigation and could not be economically used for this purpose. The water from the lake in Grand Coulee might be used in irrigating some of the crops less sensitive to alkali if liberal quantities of land plaster were applied to the land, but even then such special precautions as artificial drainage or washing down the alkali by flooding ${ }^{1}$ would probably be necessary to insure success.

\section{PUMPING PLANTS AND IRRIGATION.}

\section{PUMIPING FROII WELLS.}

Most of the water used for irrigation in Quincy Valley is pumped from wells, but a part is pumped from Moses Lake.

Power for pumping is supplied by internal-combustion engines burning distillate or crude oil. The power plants range in size from 5 to 80 horsepower, but 15 to 30 horsepower is the size of most plants designed primarily for irrigation. The pumps are either centrifugal or reciprocating, the type selected depending on the lift. The lifts range from 10 to 300 feet, and the yields from 25 to 1,000 gallons per minute. Centrifugal pumps (ordinary centrifugal or turbine) are generally used for lifts of less than 100 feet; for the greater lifts reciprocating (plunger or piston) pumps are used.

In 1916 wells were used to irrigate approximately 2,800 acres in the basin, exclusive of lands in the vicinity of Ephrata and of Soap Lake-2,300 acres being in orchard, mostly apples, and 500 acres in alfalfa and miscellaneous crops. In the Ephrata and Soap Lake regions perhaps 500 acres additional were irrigated from wells, making a total of 3,300 acres for the whole basin. Several factors, among which may be mentioned character of soil, accessibility of water supply, and nearness to transportation lines, have restricted irrigation to certain fairly well defined districts. Thus the Quincy and Winchester districts were selected for development chiefly because of the good quality of the soil and nearness to the railroad; Hiawatha Valley and the Moses Lake region because water could be obtained near the surface. All attempts to irrigate large tracts in the south-central and southern parts of the basin by pumping have resulted in failure because the soil is so porous and absorbs the water so rapidly that the land can not be covered by the ordinary irrigating stream.

1 See Dele, R. B., Ground water in San Joaquin Valley, Cal. : U. S. Geol. Survey WaterSupply Paper 398, pp. 58-61, 1916. 


\section{PUMPING FROM MOSES LAKE.}

In 1916 approximately 700 acres were irrigated by pumping from Moses Lake. The Grant Realty Co. has six pumping plants that draw from the lake, four of which were in operation in 1916. The plants range in size from 11 to 90 horsepower and are designed for capacities of 1,400 to 2,600 gallons per minute with heads of 45 to 95 feet.

\section{COST OF PUMPING.}

In calculating the cost of pumping, not only the actual expenses of operation should be considered but also all fixed charges, such as interest on the investment, depreciation, taxes, and repairs. Annual charges for depreciation and repairs on the average plant will range from 12 to 15 per cent of the cost of the equipment and interest and taxes from 7 to 9 per cent.

The cost of fuel is probably the largest item of the operating expense. With distillate costing 14 cents a gallon, the expense for fuel at 30 plants in Quincy Valley in 1916, as reported by the owners, ranged from $\$ 1.50$ to $\$ 18$ per acre-foot of water pumped. The average cost was about $\$ 2$ for an acre-foot of water lifted 50 feet. At a few plants a lower grade of distillate, known as "stove oil" or "stove distillate," costing about 6 cents a gallon, was used and the cost of pumping at these plants was materially less. The principal reason given for using the more expensive fuel is that the use of the cheaper fuel necessitates a special carbureter for the engine, but as the carbureter can be purchased at a comparatively small expense it seems poor economy to avoid an immediate outlay by continuously meeting a fuel bill that is higher than necessary.

\section{SUMMARY' AND CONCLUSIONS.}

Water for irrigation can be obtained in Quincy Valley only by pumping. In 1916 lands aggregating about 3,300 acres were irrigated by pumping from wells and about 700 acres by pumping from Moses Lake.

Power for pumping is supplied entirely by internal-combustion engines. Because of the high cost of fuel the cost of water for irrigation is high, especially throughout the central and western parts of the basin, where water must be lifted from great depths.

On the basis of the acreage now under irrigation and the probable annual contributions of water to the basalt, lake beds, and glacialoutwash deposits and to Moses Lake, it is estimated that a total of as much as 15,000 acres can be irrigated in the basin each year from these sources, the most dependable of which are the glacial-outwash deposits and Moses Lake. Irrigation projects planned to serve more than 15,000 acres are not justified by the facts at present available. 



\section{INDEX.}

Page.

Acknowledgments for aid.............. 4,95, 134 Adrian Sink, Wash, movement of water to and from

Agriculture, Department of, cooperation by $\quad 153$ by.. $\quad 38$ Agriculture in Quincy Valley, Wash ....... 139-140 in Reese River basin, Nev............ 122 in San Simon Valley, Ariz.-N. Mex...... 29-35 Alfalfa, water needed for ................. 66 Alluvial fans, occurrence of, in Reese River basin, Nev.

Alluvial slopes near mouth of Big Creek,Nev., plate showing................. 102

Analyses of ground waters........... 17, 21,54-55

Antelope Spring, Nev., spring southwest of, plate showing ................ 104

Arikaree formation, nature and occurrence of. $\quad 41$ water in ........................... 61-62

Arizona Agricultural Experiment Station; cooperation by.................

Artesia Valley, Ariz., flowing wells in ...... 26-27

Augusta Mountains, Nev., rocks composing. 100

Austin, Nev., Big Creek near................ 108

industries of........................ 96

precipitation at................... 102-103

water supply of..................... 118

Averill, J. D., acknowledgment to.......... 4

Basalt, water in, in Quincy Valley, Wash. . 147-150

Battle Mountain, Nev, industries of . precipitation at.................. 102,103-104

Rock Creek near..................... 109

water supplies in .................... 118,119

Bell's ditch; discharge of................. 110

Berlin, Nev., Reese River near............ 107

Big Creek near Austin, Nev.............. 108

Boone Creek, Nev., discharge of............ $\quad 110$ valley of, plate showing............... 104

Bowie, Ariz., precipitation at.............. 10

Bowie area, Ariz., ground water in........ 11-18 map of, showing locations of wells....... 14

Brule clay, nature and distribution of, in

Lodgepole Creek valley.......... 40-41 water in ......................... 47,62-63

Buffalo Valley, Nev., Pleistocene lake in..... 100

Bushnell, Nebr., pumping plant near....... 65-66 wells at and near................... 57,58

Chadron sandstone, stratigraphic place of.... 40 water in, in Lodgepole Valley, Wyo. and Nebr...........................

Chappell, Nebr wells at, yield of

Cheyenne County, Nebr., wells in, descriptions of....................... 58-60

Chriricahua Mountains, Ariz., description of.

Clear Creek, Nev., discharge of .

Cochise Head, Ariz., altitude of.

Columbia River, proposed improvement of...
Crab Creek, Wash., basin of, movement of surface and ground water in... 152-154

description of..................... 136-137

Cretaceous formations in Lodgepole Valley, Wyo.-Nebr., ground water in.... 63-64

Darton, N. H., cited.................... 39

Desatoya Mountains, Nev., rocks composing. $\quad 100$ Deuel County, Nebr., wellsin, descriptions of. $60-61$ Diesem, H. C., Cost of pumping for irrigation in western Nebraska............ 67-69

Dinsmore, S. C., analyses of ground water by. 54-55 Dos Cabezas Mountains, Ariz., description of. 4

Ebsen, G. E., acknowledgment to.......... ， 4

Egbert, Wyo., well at..................... 56

Equivalents, convenient................ 92-94

Fans, alluvial; occurrence of, in Reese River basin, Nev.................... 98

Farming, dry, in San Simon Valley, Ariz... 33

Feet per second, conversion of velocity in, into velocity in miles per hour... 75

Fish Creek, Nev., discharge of ............. 110

Fish Creek Mountains, Nev , rocks composing 100

Forage, raising of, in dry area............ 34

Forbes, R. H., Agriculture in the San Simon Valley......................... 29-35

Forsling; Gus., pumping plant of.........6 65-66 Fox Hills sandstone, ground water in, in Lodgepole Valley, Wyo.-Nebr... 63-64

Gallons per minute, conversion of discharge in, into discharge in second-feet..

Garland, J. B., acknowledgment to .........

Grain, raising of, in a dry area.............. 34

Grand Coulee, Wash., quality of lake water in $\quad 156$

Great Plains, escarpments in.............. 38-39

Grimes Lake, Wash., quality of water in.... 156

Ground water, analyses of ........... 17, 21,54-55

quality of ....................... 16-18, 20

temperature of ...................... 18

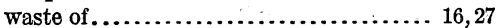

Havallah Range, Nev., rocks composing. . . 100, 101

Henshaw, F. F., acknowledgment to........ 134

Hibler, J. H., acknowledgment to......... 4

Hill, J. L., acknowledgment to............ 4

Humboldt River, Nev., flow of............. 109, 110

Humboldt River basin, Nev., artesian con-

ditions in.................... 112-114

irrigation in ........................ 119-122

reconnaissance map of parts of........... 98

springs in, data on.................... 122-129

wells in, construction of ............. 119-122

datá on........................ 122-129

See also Reese River basin.

Hydraulic conversion tables and convenient

equivalents.................... 71-94 
Tllinois Creek, Reese River above Page.

Indian Valley, Nev., origin of .............. 105-107 plate showing...................... 102 Irrigation in Lodgepole Valley, Wyo.-Nebr.. 5152,64-67

in Quincy Valley, Wash....... 131-133, 156-157 in Reese River basin, Nev............. 119-122 in San Simon Valley, Ariz.-N. Mex... 27,31-32

Julesburg, Colo., wells at, yield of...........

Kimball County, Nebr., wells in $57-58$

Lake beds in Quincy Valley, Wash., water in ............................

in Reese River basin, Nev., nature of....

in San Simon Valley, Ariz.-N. Mex., nature of......................

Laramie County, Wyo., wells in, descriptions of ........................... 56-57

Lavas, Tertiary, in Reese and Humboldt river basins, Nev............. 101

Lodgepole, Nebr., wells at, yield of .......... 59-60

Lodgepole Creek, Wyo.-Nebr., course of.... . 37 flow measurements of.................. 43-46 irrigation from...................... 51-52

terraces on........................... 38

Lodgepole Creek valley, Wyo.-Nebr., description of .................. 37-38

geology of .

ground water in, quality of............ 52-55

source and disposal of.............. 50-52

irrigation in .......................... 64-67

map of .......................... 40,64,66

physiography of..................... 38-39

precipitation in......................... $42-43$

surface waters of...................... 43-46

water in gravels of..................... 47

water in Tertiary formations in......... 61-63

water table in........................ 47-50

McCrory, J. S., acknowledgment to.......... Map scales, miles to 1 inch by ............... Meinzer, Oscar E., Ground water for irrigation in Lodgepole Valley, Wyo. and Nebr..................... 37-67

Schwennesen, A. T., and, Ground water in Quincy Valley, Wash....... 131-157

Mill Creek, discharge of................... $\quad 110$

Moore, P. W., analyses by................ 17, 21 .

Moore's Spur area, Ariz., ground water in... 19

Moses Lake, Wash., description of.......... 136 movement of surface and ground water near........................ 152-155

water for irrigation pumped from....... 157

Muddy Creek, flow of

Mullerleile, Louis, acknowledgment to........ " 134

Neill, Ernest L., field work by.............. 95

Nevada, ground water resources of ......... 95 map of, showing areas covered by groundwater papers.

Ogalalla formation, nature and occurrence of, in the Lodgepole Creek valley .... 41-42
Page.

Paradise, Ariz., precipitation at . .......... 10,11

Peloncillo Mountains, description of......... 4,5,6

Pierce, A. G., acknowledgment to ..........

Pierre shale, ground water in, in Lodgepole Valley, Wyo., Nebr............. 63,64

Pinaleno Mountains, Ariz., description of.... 4,5 Pinebluff, Wyo., wells at and near........... 56-57 Playas, occurrence of, in the Reese River basin........................ 98-99

Potter, Nebr., wells at, yield of.............. 58

Poultry raising in San Simon Valley, Ariz.N. Mex....................... 35

Pumping for irrigation, cost of............ $67-69,157$ plants for........................... 65-67

Quincy Valley, Wash., climate of........... 138-139 field work in ........................ 134 geologic section across, plate showing .... $\quad 140$ geology of . ....................... 141-145 glacial outwash in, nature and origin of... 144 water in ....................... 151-155

irrigation in . ............... 131-133, 156-157

lake beds in . ....................... 143-144

location of ............................. 131

soil and vegetation in................. 139-140

water in, quality of................. 155-156

water-bearing formations in........... 147-155

water table in . ..................... 145-146

wind-blown deposits in................ 145

Quincy Valley, Wash., and adjacent areas, map of ....................... 134

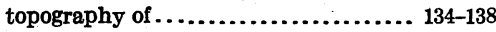

Reese River above Illinois Creek. ......... 105-107 chief tributaries of..................... 108 excavation by ......................... 100 flow of........................ 104-105, 107 Reese River basin, Nev., artesian conditions in ......................... 112-114

field work in ......................... 95

geography of ........................ 96-97

geology of . . ........................ 99-102

ground water in, quality of............ 114-118

quantity of ...................... 112

source and discharge of............ 110-111

irrigation in . . ..................... 119-122

physiography of .................... 97-99

reconnaissance map of $. . . \ldots \ldots \ldots \ldots \ldots . .98$

springs in, data on .................. 122-129

water supplies utilized in . ............ 118-119

water table in ...................... 111-112

wells in, construction of ............... 119-121

wells in, data on .................... 122-129

Reese River canyon, Nev.; head of, plate showing....................... 106

Reese River valley, Nev., low bluffs along, plate showing ................. 100

view looking westward across, plate showing ........................

view from James Litster's ranch, plate showing...................... 106

Rock Creek near Battle Mountain, Nev. 109 near its canyon................. 110

Rocky Ford Creek, Wash., movement of water to and from............. 153-154

Rodeo, N. Mex., precipitation at............. 10, 11 
Page.

Rodeo area, N. Mex.-Ariz., ground water in.. 18-21 map of, showing locations of wells and springs .

Roundtree, James, acknowledgment to....... Run-off in millions of gallons, conversion of, into run-off in acre-feet.

Run-off in millions of gallons per day, conversion of, into discharge in second-feet.

San Simon, Ariz., precipitation at.......... 10

San Simon area, Ariz., ground water in ....... 11-18 map of, showing location of wells ......... 14

San Simon Cienaga, Ariz.-N. Mex., description of $. . \ldots \ldots \ldots \ldots \ldots \ldots \ldots \ldots .6,12,18$

San Simon Creek, description of ............ 5,6 San Simon Valley, Ariz.-N. Mex., agriculture in... 29-35 artesian water in ................. 2-3,12-18 cattle raising in ................... 1-3,34-35 geology of ......................... 6-9

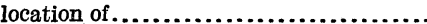
map of.

physiography of precipitation in ............. scope of report on .................... 3

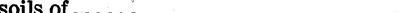

summary of ground-water data on....... 27-28

vegetation in ......................... 30-31

wells in, records of . .................... 22-26

San Jose, Ariz., settlement of ................ 29

Schwennesen; A. T., Ground water in San Simon Valley, Ariz. and N.Mex... 1-28

and Meinzer, O. E., Ground water in Quincy Valley, Wash......... 131-157

Second-feet, conversion of discharge in, into run-off in acre-feet

conversion of discharge in, into run-off in acre-feet for a year of 365 days ...

into run-off in acre-feet per month of 28 days.

per month of 29 days ........... 86-87

per month of 30 days ............ 88-89

per month of 31 days ........... 90-91

into run-off in millions of cubic feet.. $\quad 73$

into run-off in millions of gallons.....

into theoretical horsepower per foot of fall.

Second-feet per square mile, conversion of discharge in, into run-off in depth in inches

conversion of discharge in, into run-off in depth in inches per month of 28 days
Second-feet per square mile, conversion of discharge in, into run-off in depth in inches per month of 29 days......................... $78-79$

into run-off in depth in inches per month of 30 days ............. 80-81 per month of 31 days ........... 82-83 per year of 365 days............ 75

Shoshone Range, Nev., description of....... 97-98 rocks composing. ................... 100, 101 Sidney, Nebr., wells at and near, yield of.. 58-59,60. Siebenthal, C. E., cited.................. 39 Silver Creek, Nev., discharge of ........... $\quad 110$ Soap Lake, Wash., quality of water in..... 155-156 Spring Creek, Wyo., flow of................ 44 Springs, occurrence of, in San Simon Valley, Ariz.-N. Mex................ 19

Stewart Creek, Nev., discharge of........... 110 Stock raising in San Simon Valley, Ariz.N. Mex................. 1-3,34-35 Stream deposits in San Simon Valley, nature of .......................... 8,9

Sumrell, Frank, acknowledgment to........ 4

Terms, definition of .................... 71

Toyabe Range, Nev., description of......... $\quad 97$ rocks composing .................... 100, 101 Truckee group, occurrence of ............. 101 U. S. Weather Bureau, cited .......... 9, 10,42-43

Vegetables, growing of, in a dry area......... 34 Velocity in feet per second, conversion of, into velocity in miles per hour... 75 Vinson, A. E., analyses by ............... 17,21

Waring, Gerald A., Ground water in Reese River basin and adjacent parts of Humboldt River basin, Nev . . 95-129

Washburn, E. A., acknowledgment to....... 4 Wells, artesian, in San Simon Valley, Ariz.N. Mex., yield of ......... 12,14-15,26 construction of ................... 15-16, 26 in Lodgepole Creek valley, Wyo.-Nebr., yield of .....................56-61

in San Simon Valley, Ariz.-N. Mex., loss of head in .................... 14,15 maps showing locations of .......... 4,14,20 records of ........................ 22-26 Wharton, Gordon, acknowledgment to...... 4 Wind-blown deposits in Quincy Valley, Wash 145

Yakima basalt, nature of 142-143

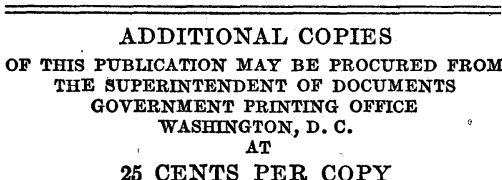

25 CENTS PER COPY 
